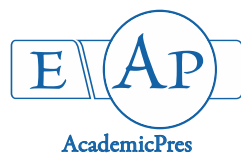

\title{
Study of Acute and Sub-Acute Toxicity of Cola millenii Leaf and Stem Bark Extracts in Albino Rats
}

\author{
Faith I. AKINNIBOSUN ${ }^{1 *}$, Lanre B. ADEWUMI \\ ${ }^{1}$ University of Benin, Department of Microbiology, Faculty of Life Sciences, PMB 1154, Benin City, Edo State, \\ Nigeria; faith.akinnibosun@uniben.edu ( ${ }^{*}$ corresponding author) \\ ${ }^{2}$ Rufus Giwa Polytechnic, Department of Science Laboratory Technology, Faculty of Applied Sciences, PMB 1019, Owo, Ondo State, \\ Nigeria; adewumibl@yahoo.com
}

\begin{abstract}
In the present study, the toxicity of monkey kola (Cola millenii) leaf and stem bark extracts were investigated in laboratory animals. The rats were orally administered with the plant extracts at gradual doses of $10 \mathrm{mg} / \mathrm{kg}, 100 \mathrm{mg} / \mathrm{kg}, 1,000 \mathrm{mg} / \mathrm{kg}$, $2,500 \mathrm{mg} / \mathrm{kg}, 3,500 \mathrm{mg} / \mathrm{kg}$ and $5,000 \mathrm{mg} / \mathrm{kg}$ b.w. and were closely monitored for $24 \mathrm{~h}$. In sub-acute toxicity, the animals were given $1,000 \mathrm{mg} / \mathrm{kg}$ b.w. and $2,500 \mathrm{mg} / \mathrm{kg}$ b.w. for 28 days. Thereafter, the effect of the extracts on the weight and haematological parameters of the rats were determined. The rats did not show any symptoms of toxicity throughout the experiment. In the sub-acute toxicity assay, starting from week two, the groups administered with 1,000 $\mathrm{mg} / \mathrm{kg}$ and 2,500 $\mathrm{mg} / \mathrm{kg}$ stem bark extract had significant $(\mathrm{p} \leq 0.05)$ lower weight compared with the other groups. In the haematological assay, there were no significant differences $(\mathrm{p} \geq 0.05)$ between the RBC and platelet counts as well as PCV, haemoglobin, urea, cholesterol, creatinine, LDL, HDL and AST level of all the groups given the extract in comparison with the control. Albeit, the level of white blood cells count, was higher in the treated groups compared with the control with concomitant significant $(\mathrm{p} \leq$ 0.05) increase in the ALT and ALP levels of the animals treated with the extracts compared with the control. Results show that Cola millenii leaf and stem bark extracts are safe for oral use, although, at higher doses, stem bark extract may cause liver damage.
\end{abstract}

Keywords: acute toxicity; Cola millenii; dose; haematology; weight

\section{Introduction}

Traditional medicine can be defined as the set of practices, knowledge and beliefs that employ plants, animals and their components to treat, diagnose and prevent illness or maintain well-being (WHO, 2012). Folk medicine has been applied from time immemorial to human health, especially as remedies for various ailments in many villages across Nigeria. Several countries all over the world explore indigenous medicine to take care of their primary healthcare needs. In Nigeria, for instance, traditional medicine is usually preferred as the first choice of treatment for at least six out of ten children suffering from malaria, while about $85 \%$ of Nigerians use and consult traditional medicine for health care, social and psychological benefits (Amupitan, 2013). The World Health Organization (WHO) has enjoined the third world countries to use the resources of traditional medicine for meeting the basic primary healthcare needs of their populace. This has been due to the many advantages of the traditional medicine such as cheap costs, affordability, acceptability and general low toxic nature.

Medicinal plants have enormous therapeutic potentials to heal many infectious diseases by avoiding many side effects. Plants have been a very good source of remedies for curing different types of diseases. Metabolites of medicinal plants are a major source of pharmacologically active substances; thus, many investigations are ongoing to ascertain the pharmacological activities of plants (Mothana et al., 2010). Throughout Africa, different people have had to depend on their knowledge of plants to protect their crops, stored products and animals from damages caused by pests. Moreover, many plants are known to be efficacious in the management of diseases and their vectors, as well as other pests. The traditional knowledge has been passed down from ancient time to successive generations and offers an effective and environment friendly pest management strategy. Tropical Africa is blessed with an array of biodiversity and indigenous knowledge system of bioactive plants whose benefits have not been fully utilized medicine and agriculture. 
Several studies have been reported about the traditional medicinal uses of Cola millenii (monkey cola). C. milleni is a tree that grows up to $12 \mathrm{~m}$ high and occasionally to $20 \mathrm{~m}$ with a low crown of arching branches, deciduous, of closed and transition forest, tending toward the drier parts, in Ivory Coast to Southern Nigeria. As a tree, it grows vigorously, and it has been called "monkey kola" in English, atewo-edun in Yoruba and achiokokoro in Igbo (Nwankwo, 2017). The bark has been reported to contain alkaloids. Odugbemi (2006) have reported the use of $C$. millenii leaves for the treatment of ringworm, scabies, gonorrhoea, dysentery and ophthalmia. The fruit is bright red in a stellate cluster; its seed is covered with a felted fibrous coal. The kernel is edible. The wood is white and very resilient. It is used in Nigeria for the stock of the crossbow and in Liberia for rat traps and bows. According to Adeniyi et al. (2004), only the leaf and the stem of $C$. millen $i$ were reported inactive at the highest concentration of $1,000 \mathrm{mg} / \mathrm{ml}$.

However, little is known about the toxicological safety profile or otherwise of the Cola millenii plant parts. It is the authors' view that the exploration of such aspects of this medically useful plant could either promote its wider use or call for caution on its use.

\section{Materials and Methods}

\section{Collection and preparation of plant samples}

The leaf and stem bark of monkey kola (Cola millenii) were harvested fresh from a forest at Iyere, Owo Local Government, Ondo State. They were then identified at the Environmental Biology Unit of Science Laboratory Technology Department, Rufus Giwa Polytechnic, Owo and voucher specimens (CMP1122B - C. millenii stem bark and CMP1124L - C. millenii leaf) were deposited at the Department of Forest Resources Technology, of the same institution. Thereafter, the samples were washed thoroughly with distilled water and air dried for 21 days at room temperature. The dried plant materials were then powdered using a mechanical grinder and later stored in previously sterilized clean plastic containers until needed for further analyses.

\section{Extraction procedure}

Ground samples were made of $100 \mathrm{~g}$ of leaves macerated in $200 \mathrm{ml}$ of solvent ( $70 \%$ ethanol) for $48 \mathrm{~h}$, with occasional stirring. Thereafter, extracts were filtered with Whatman No.1 filter paper into sterile containers and then rotary evaporator was used to dry the filtrates at $50^{\circ} \mathrm{C}$.

\section{Source of albino rats}

For the experiment, 60 albino rats $(125-130 \mathrm{~g})$ were supplied by the Department of Animal Production and Health, Faculty of Agricultural Technology, Rufus Giwa Polytechnic, Owo. They were acclimatized and maintained in wooden cage in the animal house of the Environmental Biology Unit of the Department of Science Laboratory Technology of the same institution. The rats were fed with standard rat feed.
Acute toxicity test

A two phase test, according to Lorke (1983), was adopted for the $\mathrm{LD}_{50}$ determination. In phase I, 3 groups of four albino rats (6 weeks old) were used for this determination. Each rat was orally administered with the leaf and stem bark extracts of C. millenii (reconstituted in distilled water) at gradual doses of $10 \mathrm{mg} / \mathrm{kg}, 100 \mathrm{mg} / \mathrm{kg}$ and $1,000 \mathrm{mg} / \mathrm{kg}$ body weight and observed for 24 hours. In the second phase, one (1) animal was put in a group making three groups of 1 animal each. Then, each was given the extract at doses of $2,500 \mathrm{mg} / \mathrm{kg}$ (I), 3,500 mg/ $\mathrm{kg}$ (II) and $5,000 \mathrm{mg} / \mathrm{kg}$ (III). They were monitored for 24 hours and the deaths (if any) were recorded.

\section{Sub-acute toxicity test}

The OECD guideline 407 (2008) for determination of oral toxicity of materials was used. The animals were distributed into five groups of 5 rats each. Group 1 received the control (distilled water), Group 2 received leaf extract dose of 1,000 mg $/ \mathrm{kg}$ b.w., Group 3 received leaf extract dose of $2,500 \mathrm{mg} / \mathrm{kg}$ b.w weight, Group 4 received stem bark extract dose of $1,000 \mathrm{mg} / \mathrm{kg}$ b.w. and Group 5 received stem bark extract dose of $2,500 \mathrm{mg} / \mathrm{kg}$ weight. The plant materials were given every day for 4 weeks and rat health was closely observed. The weights of the rats were recorded every week. At the expiration of the experimental period, the animals were slaughtered and the blood collected venepuncturally for blood assays in two different tubes (with and without EDTA). Packed cell volume (PCV), hemoglobin $(\mathrm{Hb})$, red blood cells $(\mathrm{RBC})$ and white blood cells (WBC), as well as platelet count were done using an automatic counter (Sysmex K21). The blood without EDTA was centrifuged at 2,500 rpm for $15 \mathrm{~min}$ to obtain the serum on which biochemical analyses were done. Standard diagnostic kits (Labkit) were used for spectrophotometric determination of alanine aminotransferase (ALT), aspartate aminotransferase (AST), alkaline phosphatase (ALP), total cholesterol, high density lipoproteins (HDL), creatinine and urea. Low density lipoprotein (LDL) concentration was calculated using the Friedewald's equation (Crook, 2006).

\section{Statistical analysis}

Unless otherwise indicated, results are expressed as means \pm SEM of three replicates. Data were subjected to one-way analysis of variance (ANOVA) using SPSS version 16.0. The Duncan's Multiple Range test was used to separate the means at the $5 \%$ level of probability.

\section{Results and Discussion}

\section{Acute toxicity profile}

Herbal remedies have a therapeutic effect and are acceptable interventions for several diseases and symptoms. The World Health Organization (WHO) has advised developing countries such as Nigeria to make use of the resources of traditional medicine for meeting the primary healthcare needs of their people. Interestingly, the demand for medicinal plants is progressively rising in industrialized nations as it is in developing countries (Abere et al, 2010). 
360

This increase in demand has necessitated also the evaluation of Cola millenii leaf and stem bark for possible toxicity in animal models, as it is one of the plants used for remedy of various disease conditions in Southwest Nigeria.

In the acute toxicity study, rats administered with the two extracts (ethanol) of both leaf and stem bark of $C$. millenii at concentrations of 10, 100, 1,000, 2,500, 3,500 and $5,000 \mathrm{mg} / \mathrm{kg}$ did not have symptoms of toxicity throughout the experimental period (Table 1). All the animals were observed to be healthy as revealed by the normal appearance of respiratory pattern, frequency and nature of movement. Moreover, there was no abnormality in the form of faeces and colour of urine. Also, no death was recorded at these doses. It can therefore be induced that oral administration of $5,000 \mathrm{mg} / \mathrm{kg}$ of $C$. millenii leaf and stem bark extracts were well tolerated in albino rats, therefore are safe for consumption. These results suggest that ethanol extracts of $C$. millenii leaf and stem bark may not be toxic after an acute exposure to $5,000 \mathrm{mg} / \mathrm{kg}$ b.w dose. Kaufmann et al. (1999) had concluded that compounds with oral $\mathrm{LD}_{50}$ (rat) of $\geq 5,000 \mathrm{mg} / \mathrm{kg}$ should be considered as practically harmless. Thus, oral administration of $C$. millenii leaf and stem bark at a concentration of $5,000 \mathrm{mg} / \mathrm{kg}$ b.w. may be considered safe in mammals (James and James, 2002).

\section{Sub-acute toxicity profile}

In the sub-acute toxicity assay, the effect of the two parts of the $C$. millenii on the body weight gain by experimental animals is presented in Table 2 . The table showed that after one week exposure, the weight of rats treated with 2,500 $\mathrm{mg} / \mathrm{kg}$ was significantly lower compared with the control and others, whereas, from week two upwards, the groups administered with $1,000 \mathrm{mg} / \mathrm{kg}$ and $2,500 \mathrm{mg} / \mathrm{kg}$ stem bark extract had significant $(\mathrm{p} \leq 0.05)$ lower weight compared with the other groups. This indicates that the stem bark extract of $C$. millenii may have some effect on nutrient uptake. Changes in body weight of an animal is a sensitive parameter of the health status of the animal according to Larbie et al. (2011), hence the lower weight of animals treated with stem bark extracts may be indicative of adverse effect on the appetite stability of the animals, thereby calling for caution in the administration of this part in its usage in preparation of medicine by the traditional practitioners. However, the non-significant difference in the weight of the animals treated with leaf extracts versus the control suggests that $C$. millenii leaf extract did not disturb the normal metabolic activities of the rats (Akhila et al., 2007), or their appetite.

Table 1. Oral lethal dose of $C$. millenii leaf and stem bark in albino rats

\begin{tabular}{cccc}
\hline Dose $(\mathrm{mg} / \mathrm{kg})$ & Leaf & Stem bark \\
\hline Phase I & & $0 / 4$ & $0 / 4$ \\
10 & $0 / 4$ & $0 / 4$ \\
100 & $0 / 4$ & $0 / 1$ \\
1,000 & $0 / 1$ & $0 / 1$ \\
Phase II & $0 / 1$ & $0 / 1$ \\
2,500 & $0 / 1$ & 0 \\
3,500 & & 0 \\
\hline
\end{tabular}

Table 2. The effect of Cola millenii extracts on body weight gain in the control and treated rats after 28 days exposure

\begin{tabular}{|c|c|c|c|c|c|}
\hline \multirow{2}{*}{ Week/Dose } & \multirow{2}{*}{$\begin{array}{l}\text { Control } \\
0 \mathrm{mg} / \mathrm{kg}\end{array}$} & \multicolumn{2}{|c|}{ Leaf } & \multicolumn{2}{|c|}{ Stem bark } \\
\hline & & $1,000 \mathrm{mg} / \mathrm{kg}$ & $2,500 \mathrm{mg} / \mathrm{kg}$ & $1,000 \mathrm{mg} / \mathrm{kg}$ & $2,500 \mathrm{mg} / \mathrm{kg}$ \\
\hline 0 & $128.3 \pm 0.58$ & $127.5 \pm 0.08$ & $128.6 \pm 0.01$ & $128.0 \pm 0.00$ & $128.5 \pm 0.02$ \\
\hline 1 & $133.0 \pm 1.00$ & $135.7 \pm 0.58$ & $136.7 \pm 1.53$ & $131.0 \pm 0.00$ & $130.3 \pm 0.58^{*}$ \\
\hline 2 & $140.3 \pm 0.58$ & $142.2 \pm 1.15$ & $141.2 \pm 0.58$ & $137.7 \pm 2.08^{*}$ & $136.4 \pm 1.15^{*}$ \\
\hline 3 & $145.0 \pm 1.00$ & $149.6 \pm 1.53$ & $150.7 \pm 0.58$ & $143.0 \pm 1.00^{*}$ & $142.1 \pm 1.73^{*}$ \\
\hline 4 & $159.3 \pm 0.58$ & $159.0 \pm 1.15$ & $160.1 \pm 1.00$ & $156.3 \pm 0.58^{*}$ & $156.8 \pm 1.53^{*}$ \\
\hline
\end{tabular}

Note: ${ }^{*}$ between columns denote significant differences (Duncan test, $\mathrm{p}<0.05$ )

Table 3. The effect of leaf and stem bark extract of Cola millenii on blood parameters of rats

\begin{tabular}{|c|c|c|c|c|c|}
\hline \multirow{2}{*}{ Parameters } & \multirow{2}{*}{$\begin{array}{l}\text { Control } \\
0 \mathrm{mg} / \mathrm{kg}\end{array}$} & \multicolumn{2}{|c|}{ Leaf } & \multicolumn{2}{|c|}{ Stem bark } \\
\hline & & $1,000 \mathrm{mg} / \mathrm{kg}$ & $2,500 \mathrm{mg} / \mathrm{kg}$ & $1,000 \mathrm{mg} / \mathrm{kg}$ & $2,500 \mathrm{mg} / \mathrm{kg}$ \\
\hline $\mathrm{RBC}\left(\times 10^{6} / \mu \mathrm{l}\right)$ & $6.12 \pm 0.00$ & $6.22 \pm 0.18$ & $6.17 \pm 0.10$ & $6.31 \pm 1.02$ & $6.28 \pm 0.02$ \\
\hline $\operatorname{WBC}\left(\times 10^{3} / \mu \mathrm{l}\right)$ & $4.73 \pm 0.01$ & $5.19 \pm 0.07$ & $6.45 \pm 0.17^{*}$ & $7.11 \pm 2.15^{*}$ & $7.75 \pm 0.00^{*}$ \\
\hline Platelets $\left(\right.$ x $\left.10^{3} / \mu \mathrm{l}\right)$ & $295.13 \pm 0.10$ & $301.78 \pm 0.10$ & $300.41 \pm 1.20$ & $304.05 \pm 0.10$ & $302.11 \pm 0.10$ \\
\hline $\operatorname{PCV}(\%)$ & $37.20 \pm 0.00$ & $38.02 \pm 0.00$ & $37.50 \pm 0.08$ & $37.64 \pm 0.15$ & $36.89 \pm 0.07$ \\
\hline $\mathrm{HB}(\mathrm{g} / \mathrm{dl})$ & $11.31 \pm 0.30$ & $11.45 \pm 0.10$ & $11.09 \pm 1.00$ & $12.02 \pm 0.08$ & $11.29 \pm 0.00$ \\
\hline
\end{tabular}


Table 4. The effect of leaf and stem bark extract of Cola millenii on serum biochemical parameters of rats

\begin{tabular}{|c|c|c|c|c|c|}
\hline \multirow{2}{*}{ Parameters } & \multirow{2}{*}{$\begin{array}{l}\text { Control } \\
0 \mathrm{mg} / \mathrm{kg}\end{array}$} & \multicolumn{2}{|c|}{ Leaf } & \multicolumn{2}{|c|}{ Stem bark } \\
\hline & & $1,000 \mathrm{mg} / \mathrm{kg}$ & $2,500 \mathrm{mg} / \mathrm{kg}$ & $1,000 \mathrm{mg} / \mathrm{kg}$ & $2,500 \mathrm{mg} / \mathrm{kg}$ \\
\hline $\operatorname{ALT}(\mathrm{IU} / \mathrm{L})$ & $52.73 \pm 0.15$ & $53.12 \pm 0.18$ & $51.77 \pm 0.06$ & $68.08 \pm 0.05^{*}$ & $69.68 \pm 1.00^{*}$ \\
\hline $\operatorname{AST}(\mathrm{IU} / \mathrm{L})$ & $19.11 \pm 2.15$ & $20.07 \pm 0.09$ & $19.32 \pm 0.15$ & $18.22 \pm 0.10$ & $18.35 \pm 0.00$ \\
\hline $\operatorname{ALP}(\mathrm{IU} / \mathrm{L})$ & $87.21 \pm 1.16$ & $95.11 \pm 0.58^{*}$ & $96.74 \pm 0.01^{*}$ & $104.18 \pm 0.20^{*}$ & $119.17 \pm 0.20^{*}$ \\
\hline Cholesterol $(\mu \mathrm{mol} / \mathrm{L})$ & $2.05 \pm 0.10$ & $2.02 \pm 0.18$ & $2.11 \pm 0.01$ & $2.09 \pm 0.00$ & $2.14 \pm 0.10$ \\
\hline $\mathrm{HDL}(\mu \mathrm{mol} / \mathrm{L})$ & $0.78 \pm 0.00$ & $0.81 \pm 0.02$ & $0.84 \pm 0.25$ & $0.79 \pm 0.00$ & $0.82 \pm 0.04$ \\
\hline $\mathrm{LDL}(\mu \mathrm{mol} / \mathrm{L})$ & $1.22 \pm 0.01$ & $1.21 \pm 0.07$ & $1.26 \pm 0.10$ & $1.25 \pm 0.10$ & $1.28 \pm 0.30$ \\
\hline Urea $(\mu \mathrm{mol} / \mathrm{L})$ & $11.80 \pm 0.03$ & $10.61 \pm 0.10$ & $10.92 \pm 0.08$ & $10.49 \pm 0.20$ & $10.68 \pm 0.58$ \\
\hline Creatinine $(\mu \mathrm{mol} / \mathrm{L})$ & $80.07 \pm 1.20$ & $83.60 \pm 2.15$ & $85.01 \pm 3.11$ & $81.22 \pm 4.12$ & $83.41 \pm 0.10$ \\
\hline
\end{tabular}

Note $^{*}=$ significantly different compared to control at $\mathrm{p} \leq 0.05$

In the haematological assay, there were no significant differences $(\mathrm{p} \leq 0.05)$ between the RBC and platelet counts, as well as PCV, haemoglobin and AST level of all the groups administered with the extracts compared with the control. However, the level of white blood cells count was higher in the treated groups in comparison with the untreated group (control). Also, there was a significant $(\mathrm{p} \leq 0.05)$ increase in the ALT and ALP levels of the animals treated with the plant extracts compared with the control. The lack of significant difference $(\mathrm{p} \leq 0.05)$ in most of the blood indices among the treated rats and the control indicates the safety of the plant extracts (Frank, 2008). Although, the significantly higher level of WBC in the rats treated with the extracts at higher dose suggests that at higher concentration, the plant material may elicit immune response in animals. Furthermore, the non-significant difference in the RBC and haemoglobin concentration in all the groups indicates that the extracts may not induce anaemia in animals, thus making it safe. In the same way, results do not show any haematopoietic ability for the extracts, as there was no observation of increase in the red blood cells of the animals (Gadanya et al., 2011). No significant differences were observed in creatinine and urea concentration in the serum of all the treated rats and the control, suggesting no kidney damaging effect (PatrickIwuanyanwu et al., 2012). Furthermore, there were no significant differences in the total cholesterol, LDL and HDL of all the groups and this is an indication that the extracts had no effect on lipid metabolism of the experimental animals (Barnett and O'Gara, 2003). ALT, AST and ALP concentrations in blood plasma are an indicator of liver health. Therefore, the significantly high concentration of alanine aminotransferase and alkaline phosphatase in the rats given the stem bark extract of $C$. millenii suggests a possible deleterious effect on rat liver. Therefore, it should be used with caution in the treatment of ailments by the traditional medical practitioners.

\section{Conclusions}

Based on the observations from the present study, it is evident that Cola millenii leaf and stem bark extracts are generally safe for oral use. However, at higher doses, stem bark extract may cause liver damage, therefore, the herbal preparations that contain C. millenii stem bark should be administered with caution and prolonged use may not be advisable.

\section{Conflict of Interest}

The authors declare that there are no conflicts of interest related to this article.

\section{References}

Abere TA, Okolo PE, Agoreyo FO (2010). Antidiarrhoea and toxicological evaluation of the leaf extract of Dissotis rotundifolia and Triana melastomatacea. BMC Complement Alternative Medicine 10(1):71.

Akhila JS, Shyamjith D, Alwar MC (2007). Acute toxicity studies and determination of median lethal dose. Current Science pp 917-920.

Amupitan TA (2013). Ethnobotanical survey of medicinal plants in Biu Local Government of Borno state, Nigeria. Comprehensive Journal of Herbs and Medicinal Plants 2(1):7-11.

Barnett HA, O'Gara G (2003). Diabetes and the heart. Clinical Practice Series. Churchill.Livingstone, UK, Edinburgh pp 11-32.

Gadanya AM, Sule MS, Atiku MK (2011). Acute toxicity of 'agadagi' tea on rats. Bayero Journal of Pure and Applied Sciences 4(2):147-149.

James S, James C (2002). Encyclopedia of pharmaceutical technology, 2nd ed, pp 70-79.

Kaufmann PB, Cseke LJ, Warber S, Duke JA, Brielmann HL (1999). Natural products from plants. CRC Press, Boca-Raton, Florida pp 183205.

Larbie C, Arthur FKN, Woode E, Terlabi EO (2011). Evaluation of acute and sub-chronic toxicity of Annona muricata (Linn.) aqueous extract in animals. European Journal of Experimental Biology 1(4):115-124.

Lorke D (1983). A new approach to tropical acute toxicity testing. Archives of Toxicology 53:275-287.

Mothana RAA, Abdo SAA, Hasson S, Athawab FMN, Alaghbari SAZ, Lindequist $\mathrm{U}$ (2010). Antimicrobial, antioxidant and cytotoxic activities and phytochemical screening of some Yemeni medicinal plants. Evidence Based Complementary and Alternative Medicine 7(3):232330.

Nwankwo CE (2017). Antimicrobial and spectroscopic analyses of Cola millenii K. Schum. MSc dissertation in the Department of Biological Sciences, College of Natural Sciences submitted to the School of Postgraduate Studies, Redeemer's University, Ede, Nigeria.

OECD (2008). Organization for Economic Cooperation and Development. Repeated dose oral toxicity test method in OECD Guidelines for testing of chemicals, No 407,Paris, France. 
362

Patrick-Iwuanyanwu KC, Amadi U, Charles IA, Ayalogu EO (2012). Evaluation of acute and sub-chronic oral toxicity Study of baker cleansers bitters - A polyherbal drug on experimental rats. EXCLI Journal 11:632-640.
World Health Organization (WHO) (2012). Traditional medicine. Health topics. Retrieved 2018 August 20 from http://dx:doi.org/10:1155/2012/52487. 